\title{
What Motivates Brazilian Academic Researchers to Transfer Technology?
}

\author{
Lisiane Closs', Gabriela Ferreira², Vinicius Brasil ${ }^{3}$, Claudio Sampaioº, Marcelo Perin ${ }^{5}$
}

\begin{abstract}
This study investigated what motivates Brazilian academic researchers to get involved in University-Industry Technology Transfer (UITT) and deterrents to contributing to this process. The research relied on interviews with experienced academic scientists and managers from four universities in Brazil. Determination, persistence and entrepreneurship, related to motivational types Self-direction and Stimulation, were prominent. Hedonism, Achievement and Power - highlighting a shift in their professional identity - were also observed. Universalism type involved opening career opportunities, awakening and maintaining the interest of students. The major motivational goals were: generate resources, solve problems, professional challenge, personal gains, personal gratification, academic prestige, competition, and solving problems of society. Factors that discouraged researchers were: time required for UITT, lack of incentive, innovation environment, and fear of contravening university rules, among others. Knowledge of motivational profiles of academic scientists favors the development of incentive policies and programs for UITT, helping to attract and retain qualified researchers at Brazilian universities.
\end{abstract}

Keywords: technology transfer; university-industry; academic scientist; motivation.

\footnotetext{
'Escola de Administração - Universidade Federal do Rio Grande do Sul.Address: Rua Washington Luiz, 855- Centro - Porto Alegre - RS Brasil - ZipCode: 900 I0-460 - Phone: +55 5133083536 / Fax: + 55 5I 3308 399I. Email: lisiane.closs@ufrgs.br

2,3,4,5 Faculdade de Administração, Contabilidade e Economia - Pontifícia Universidade Católica do Rio Grande do Sul. Address:Avenida Iparanga 668I, Partenon - Porto Alegre - RS - Brasil - ZipCode: 90619-900.
} 


\section{Introduction}

The current highly competitive global environment intensifies the relevance of knowledge. Against this backdrop, University-Industry (UI) Technology Transfer (TT) is gaining ground as an alternative for companies in encouraging innovation and for universities to obtain additional resources for research (Etzkowitz, 2004).

In Brazil, the knowledge generated in universities is a valuable source for the development of new technologies, and recognition of the importance of formal University-Industry technology transfer (UITT) is growing (Garnica and Torkomian, 2009; Dalmarco et al., 20I I; Closs and Ferreira, 2012). Since 2002, the country has seen a rapid increase in academic patent applications, reflecting greater interest among scientists in intellectual property (IP) and TT (Póvoa, 2008).

According to Thursby and Thursby (20II), the rise in the licensing of patented inventions is associated to greater inclination on the part of professors to register patents. Several studies highlight the vital contribution of academic inventors throughout the UITT process, from communicating to marketing the invention (Hoye and Pries, 2009; Thursby, Fuller and Thursby, 2009; Garnica and Torkomian, 2009; Closs et al., $2012 b)$. However, there are few that seek to achieve a greater understanding of this central figure in the discovery of technologies and UITT: the academic scientist (Jain, George and Maltarich, 2009; Siegel et al., 2004; D'Este et. al, 20I2). In particular, there is little research into their motivations or factors that discourage them from participating in this process (Baldini, 20 I I; Baldini et al., 2007), especially in Brazil.

In order to bridge this theoretical gap, this study aims to investigate what motivates Brazilian academic researchers to get involved in UITT, as well as deterrents to contributing to this process. To that end, a basic interpretive qualitative approach was adopted (Merriam, 2002). The research relied on interviews with academic scientists and managers from four universities in the country, with experience in the UITT process.

Thus, the present study aims to contribute towards expanding the literature on the theme through theoretical contributions of Organizational Psychology, in order to indentify, analyze and systemize the motivations and motivational goals of these professionals. This knowledge can assist in developing motivational policies and programs to encourage UITT in universities, attracting and retaining academic talent in the country.

To achieve the proposed objectives, the article is structured as follows: Section 2 addresses TT within the context of Brazilian universities. Section 3 explores motivations and deter- rents for researchers involved in UITT. Section 4 describes the methodological procedures adopted in this study. Section 5 details the results obtained, section 6 discusses the findings and section 7 presents the final considerations.

\section{Within the context of Brazilian universities}

Despite the increased importance of formal management of IP and TT in the academic setting in Brazil (Guarnica and Torkomian, 2009), there is still no legislation to standardize the operation of Technology Transfer Offices (TTO). National incentive policies for $U-I$ cooperation are recent, and there is a wide range of procedures and criteria for establishing licensing formats to fix prices or royalties (Fujino and Stal, 2007).

Gimenez, Bonacelli and Carneiro (2012) report that even at Unicamp - the second largest holder of patents among Brazilian universities - teaching regarding IP still depends solely on the interest and ability of professors, based on individual initiatives rather than general university guidelines. The time required and high costs involved in registering and maintaining patents (Zawislak and Dalmarco, 20I I) have also compromised UITT, as has the need to adapt the language of the discovery to INPI standards for writing the patent application (Corrêa, 2007).

In the production sector, there are almost no investments in strategic fields, such as semiconductor, pharmaceutical and chemical sectors, which generate cutting edge technology and are capable of developing products that incorporate these areas (Corrêa, 2007). This constitutes a barrier to UITT, since the absorption capacity of industry is essential in incorporating new products, equipment, materials and prototypes, the TT channels most strongly related to patents (Póvoa, 2008). Moreover, there is no corporate culture of using universities as technology sources (Santana and Porto, 2009). In addition, given that academic technologies tend to be incipient, significant effort and investment is required to achieve the final product (Póvoa and Rapini, 2010).

A recent change has seen increased interest in academic patents on the part of researchers, influenced by factors such as: the creation of TTOs at universities; a larger number of researchers completing doctorates/internships abroad; diffusion of successful cases of patent management by universities in the United States; expansion of the literature on protecting and exploiting IP rights in academia; information exchanges between institutions via the internet; and debate surrounding the new patent law (Póvoa, 2008). 
Academic inventors in UITT: motivations and deterrents

The determinants of human motivations involve variables such as personality traits, intellectual and cultural resources, as well as beliefs and values that give meaning to personal needs, transforming them into goals, intentions and action (Bergamini, 2008). Tamayo and Paschoal (2003) identified ten common motivations in intercultural research conducted on different continents, as well as their specific aims (motivational goals), summarized in Table I.

The first five motivational types in the chart are directly associated with the individual and related to goals such as having autonomy, taking on challenges, and achieving satisfaction or success. The subsequent types (conformity, tradition, benevolence) aim at satisfying motivational goals related to family, the organization and society, while security and universalism involve both personal interests and those of others.

Academic researchers are sensitive to a range of incentives, whose importance varies depending on their field and individual characteristics. In a study of Italian scientists analyzing motivation patterns for researchers in patenting their inventions, Baldini (20II) identified the opportunity to exchange knowledge and prestige/reputation among their motivational goals. Likewise, Baldini, Grimaldi and Sobrero (2007) found that prestige, visibility and reputation represented new stimuli for studies and were among the main motivational goals in the involvement of researchers in this process.
Incentives for researchers were also linked to obtaining additional funding to maintain the students and equipment in their laboratories, as well as personal financial gains (Siegel et al., 2004; Link, Siegel and Bozeman, 2007). Studies show that a higher percentage of royalties for academics involved in UITT also serves as a motivating factor (Baldini, 2010; Caldera and Debande, 2010).

Motivational goals among Brazilian researchers are similar to those observed for academic scientists involved in UITT in an international context. Among the primary incentives were the possibility of gaining additional resources to fund equipment, reagents and students to conduct laboratory research (Closs and Ferreira, 20I2). Economic gains are associated with other UITT motivating factors, such as better use of equipment and greater interaction with the market (Santana and Porto, 2009; Closs and Ferreira, 2012).

Success cases also encouraged patenting and licensing by other researchers (Baldini, 2006). In addition, the experiences of researchers and staff at a pioneering Brazilian university in the UITT process provided new insights and brought gratifications that encouraged more researchers to attempt similar feats (Closs et al., 20I2b).

The search for solutions to problems was another important motivator in generating research that resulted in patent applications, whether to meet the specific needs of the researcher, the laboratory or corporate and social demands (Closs et al., 2012b). Social recognition and the acknowledgement of peers through the generation of public benefits

\begin{tabular}{|l|l|}
\hline Motivation & Metas motivacionaisMotivational goals \\
\hline Self-direction & $\begin{array}{l}\text { To have autonomy, decide/participate in decisions, control the organization and execution of } \\
\text { work }\end{array}$ \\
\hline Stimulation & $\begin{array}{l}\text { To experience challenges and strong emotions at work and in life, explore, innovate, acquire } \\
\text { new knowledge }\end{array}$ \\
\hline Hedonism & To seek pleasure and avoid suffering, experiencing satisfaction and well-being at work \\
\hline Achievement & $\begin{array}{l}\text { To achieve personal success, demonstrate competence, be influential, achieving as a person } \\
\text { and professional }\end{array}$ \\
\hline Power & To enjoy prestige, seek social status and control by dominating people and information \\
\hline Conformity & $\begin{array}{l}\text { Control impulses, trends and behaviors harmful to others and that infringe the rules and expec- } \\
\text { tations of society and the organization }\end{array}$ \\
\hline Tradition & To respect and accept the traditional customs of society and the organization \\
\hline Benevolence & Provide for the general welfare of family members and those from groups of reference \\
\hline Security & $\begin{array}{l}\text { Value personal health and safety and that of loved ones, occupational safety, harmony and the } \\
\text { stability of society and the organization }\end{array}$ \\
\hline Universalism & $\begin{array}{l}\text { Understanding, tolerance, seeking well-being for society as a whole and the organization in } \\
\text { which they work, protective of nature }\end{array}$ \\
\hline
\end{tabular}

Table I. Motivations and Motivational goals

ISSN: 07I 8-2724. (http://www.jotmi.org)

Journal of Technology Management \& Innovation (c) Universidad Alberto Hurtado, Facultad de Economía y Negocios. 
also encouraged researchers to get involved in this process. In addition to these motivations, the patenting of research results and the possibility of financial gains fueled competition between researchers, leading to new patenting attempts and feeding the UITT process (Closs et al., 20I2b).

In line with the classification by Tamayo and Paschoal (2003), Table 2 summarizes the primary motivators identified among academic researchers in the literature, as well as their corresponding motivational goals.

Although motivation is an internal predisposition, people tend to become discouraged when they are unable to secure the conditions needed to meet their expectations (Bergamini, 2008). Academic inventors act in accordance with their motivational goals, established based on their intrinsic personal needs, in the event that conditions are in place (extrinsic factors) to satisfy these aims (Bergamini, 2008). Thus, adequate policies are needed to avoid discouraging these academic talents.

Difficulty balancing time between research, the patenting process and teaching is a deterrent for Brazilian researchers (Santana and Porto, 2009; Closs et al., 2012a). Caldera and Debande (2010) found that regulations addressing such conflicts of interest favored university participation in R\&D and licensing contracts. Success cases are important incentives for patenting and licensing applications, although overemphasizing these experiences may discourage other researchers from contributing to these activities (Baldini, 2006).

Inadequate rewards also hamper the efficiency of this process (Baldini, 20I0; Caldera and Debande, 20I0). The time required and high costs involved in registering and maintaining patents are additional deterrents to participation by researchers, as well as the need to adapt the language of the discovery to INPI standards for writing the patent application (Correa, 2007; Closs and Ferreira, 20I2). Lack of communication and information in university-industry interaction as well as the profile of companies, generally wary of taking risks, further discourages researcher involvement in the UITT process (Closs et al., 2012a).

\section{Methodological Procedures}

The research conducted was qualitative in nature, aimed at understanding the makeup and interpretations of realities that change over time, within a specific context and at a given moment. A basic interpretive qualitative approach was adopted (Merriam, 2002), focusing on understanding experiences from the perspective of those involved in the phenomenon under study.

\begin{tabular}{|l|l|}
\hline Motivation & Motivational goals \\
\hline Self-direction & Securing funds for research to maintain students, reagents and equipment \\
\hline Stimulation & Insights, exchanging knowledge, greater interaction with the market \\
\hline Hedonism & Financial gains, gratification \\
\hline Achievement & Success, solving problems \\
\hline Power & Prestige, visibility, reputation, competition, financial gains \\
\hline Universalism & Solving the problems of society \\
\hline
\end{tabular}

Table 2. Motivations and motivational goals of academic scientists for UITT

\begin{tabular}{|c|c|c|c|c|}
\hline $\begin{array}{c}\text { University } \\
\text { (year founded) }\end{array}$ & $\begin{array}{c}\text { PUCRS } \\
(1948)\end{array}$ & $\begin{array}{c}\text { PUC-Rio } \\
(1940)\end{array}$ & $\begin{array}{c}\text { USP } \\
(1934)\end{array}$ & UFMG \\
\hline Sector & Private & Private & State Government & Federal Government \\
\hline $\begin{array}{c}\text { Supporting struc- } \\
\text { ture for UITT (year } \\
\text { founded) }\end{array}$ & $\begin{array}{c}\text { Science and Tech- } \\
\text { nology Park } \\
(2003)\end{array}$ & $\begin{array}{c}\text { Genesis Institute- } \\
\text { Entrepreneurship and } \\
\text { Incubator (1997) } \\
\text { TTO (2003) }\end{array}$ & $\begin{array}{c}\text { USP Innovation Agency } \\
\text { TTO (2005) }\end{array}$ & $\begin{array}{c}\text { Coordination for Technolo- } \\
\text { gy Transfer and Innovation } \\
(1997)\end{array}$ \\
\hline Main UITT areas & $\begin{array}{c}\text { Chemistry, Biolo- } \\
\text { gy, Health }\end{array}$ & $\begin{array}{c}\text { Engineering and Infor- } \\
\text { mation Technology }\end{array}$ & $\begin{array}{c}\text { Engineering and Health } \\
\text { (São Paulo Branch) }\end{array}$ & Chemistry, Biology, Pharmacy \\
\hline
\end{tabular}

Table 3. Profile of universities involved in the study

ISSN: 07 I8-2724. (http://www.jotmi.org)

Journal of Technology Management \& Innovation @ Universidad Alberto Hurtado, Facultad de Economía y Negocios. 
Based on the theoretical framework, an interview schedule was drawn up and categories established for data analysis (Merriam, 2002). Participants in the study were from 4 Brazilian universities, of which two were government institutions and two private, recognized for their active role in UITT, namely: the Federal University of Minas Gerais (UFMG); University of São Paulo (USP); Pontifical Catholic University of Rio de Janeiro (PUC-RJ); and Pontifical Catholic University of Rio Grande do Sul (PUCRS), whose profiles are described in Table 3.

Data were collected through semi-structured interviews and supplemented with observations and information obtained from university documents and websites. Subjects were academic inventors, chosen for their experience in UITT processes, particularly those involving the patenting and licensing of technologies and/or the formation of academic spin-offs, as well as managers of the TT departments of the universities studied. Table 4 shows the interviewees from each university.

An inductive approach was used for data analysis, identifying recurring patterns and themes in the statements of interviewees (Merriam, 2002). By listening to the interviews and reading the transcripts, themes and excerpts representative of each one were identified and organized systematically. The results, presented below, describe the motivations of academic inventors to engage in UITT, as well as aspects that discouraged their involvement in this process.

\section{Results}

Academic structures created to support UITT activities in the universities studied are somewhat recent. Though pioneers in the country, these structures were founded between 1997 and 2005 (see Table 4), which suggests little maturity in the development and institutionalization of this process in the universities. As such, most subjects first experienced and became interested in UITT abroad, through contact with researchers involved in the process at international universities, where they realized the potential for research results to evolve into developing products.

Despite growing recognition and increasing value given to the various UITT incentive initiatives underway at universities, it is apparent that the process has evolved in Brazil largely due to the entrepreneurial nature and individual effort of researchers, as illustrated in the following statement:

[...] it began with someone who decided to apply for patent " $x$ " himself, learnt how to write, did it alone. [...] and others followed suit; entrepreneurs. They pursued it: how do I do it? How can I have my own company? [...] they're the ones that make things happen, that carry the banner at the forefront, while in the mind of the masses it's not important. [TT manager at UFMG]

One of the most prominent motivational goals for involvement in UITT by researchers and academic managers was the possibility of generating resources for studies, including funding to maintain students, and purchase equipment and reagents. The quest for autonomy in research is even more relevant in private universities, which receive less government funding and have a greater need for sustainability. This is aptly demonstrated in the following statement by the TT manager at PUC-Rio:

[...] some [researchers] want to expand their areas of study, their groups, and to maintain these groups they need partnerships, because they're not subsidized by the government. [...] so how can they maintain their laboratories? Only by partnering with companies. Because in each contact they make, they'll do a job and buy some equipment, which they'll then use in research.

The concern over securing funds for research, the survival of study groups and the desire to "be independent from public authorities", as expressed by a UFMG inventor, also stimulated the involvement of researchers in UITT at public universities.

The search for solutions to problems generated research that resulted in patent applications, licenses and/or the creation of academic spin-offs, either to cater to the specific needs of the researcher, laboratory, companies or the government. According to a researcher in molecular biology at PUCRS,

\begin{tabular}{|l|l|l|l|l|}
\hline & PUCRS & PUC-Rio & USP & UFMG \\
\hline Managers & 3 & 3 & 2 & 4 \\
\hline Inventors & 6 & 2 & 3 & 5 \\
\hline Total (28) & 9 & 5 & 5 & 9 \\
\hline
\end{tabular}

Table 4. Number of personal interviews

ISSN: 07I 8-2724. (http://www.jotmi.org)

Journal of Technology Management \& Innovation (c) Universidad Alberto Hurtado, Facultad de Economía y Negocios. 
It's [research] normally linked to the researcher's need to solve a problem, so he investigates to solve it. But it's always based on his own research, his academic interest, focusing, for example, on the needs of the government, on health.

Despite being involved in TT, many researchers report they are motivated by carrying out the initial basic research, with UITT occurring as a result of this research, as illustrated below:

I enjoy the basic research. If I interact with a company and they're interested in taking it forward I think it's great. But at the moment it's not my intention to take it all the way myself... [...] I do the research up to a certain point, and if somebody comes forward willing to do the development and such, l'm very open to it. [Researcher in Biochemistry and Immunology from UFMG]

For many participants, the personal and professional challenge of the UITT process was an additional motivator for participation. In the words of a researcher from the Chemistry and Molecular Biology department of PUCRS: "I was motivated by the personal challenge of securing a patent for someone to market. That was my objective, it was demanding". The learning inherent in these challenges was also highlighted:

Funding often comes from research development authorities. If it doesn't work out, then it's fine. [...] It's not very challenging. I think you learn very little that way. [...] So we have to make things happen, right? So we invent. [Researcher in the Pharmacy department at USP]

Most researchers are reluctant to openly cite making money as an incentive for UITT. This is partly due to the strong influence of Catholicism in Brazilian culture. According to an Engineering researcher at UFMG, "it's a sin to make money in Brazil", especially in the academic sector. Nevertheless, there is a notable effort on the part of some academics to overcome this taboo. One researcher, the creator of an academic spin-off from USP, emphasizes the need for a change in values, remarking that

innovating is something you do to get rich honestly; it's a value that Brazilians need to embrace. Here there's always someone looking to profit, to get rich using someone else's money.
The personal gratification and pride achieved through involvement in UITT also encouraged academic scientists:

[...] once he secures a patent license for a company and the company turns the researcher's idea into a product, which was made possible because of his research that the company materialized and put on the market, without doubt it's a source of great pride for any researcher. [TTO manager at PUCRS]

The personal satisfaction and recognition gained from successful UITT experiences and their dissemination in academia led other researchers to become involved in the process. In addition to prestige for the professor, UITT also brings prestige to the university, attracting students, an element underscored by a researcher from PUC-Rio and of great importance to private institutions.

Earning recognition for their work is another motivator for researchers in UITT.As stated by a researcher from the Department of Biochemistry and Immunology at UFMG,

you get a lot of recognition when you move on from more basic work, the community recognizes that [...] I was interviewed by Veja magazine. I spoke about my basic research for two hours and about the applied research for Io minutes. Only the applied research was included in the article [...] it gives the group visibility. [...] it's an achievement.

Licensing research results, the creation of academic spinoffs through participation by professors and the prospect of possible financial gains stimulated competition between the scientists, encouraging other colleagues to get involved in UITT.According to a resercher at PUCRS, colleagues think:

[...] he's rich. He's going to get $33 \%$. They're not sure how much l'll get $33 \%$ of, but that's where the interest starts [...] And the competition begins $[. .$.$] They think: it's not like he's a$ genius, right? I can do it too. So several of my colleagues from the unit decided: I'm going to try for a patent too.

In addition to personal aspirations, academic scientists also revealed motivational goals centered on catering to the interests of others, such as maintaining student motivation. A Pharmotechnics researcher from USP remarked,

It's much more motivating for students to work on a project that will eventually be on the market. They enjoy it because they

ISSN: 07I 8-2724. (http://www.jotmi.org) 
can see a connection to what's happening in the outside world. [...] You have to keep them motivated.

Both TT managers and researchers highlighted their involvement in UITT to generate new career opportunities for students, either as employees in companies, thereby continuing the research and product development they began as students, or as entrepreneurs, creating their own companies based on research results, among other potential professional possibilities.

Generating solutions that contribute to society also encouraged academics to conduct studies and TT. In the words of a researcher from the field of biochemical pharmacology at USP, the motivation for many researchers is

turning our research into something. A product that's useful to society and can generate exchange value for Brazil. [...] we didn't have technological development. And I think we need that nowadays.

There is often more than one motivational goal for involvement in UITT.A comment by a researcher in the Chemistry Department at UFMG and partner in an academic spin-off illustrates this point by simultaneously expressing the desire to generate solutions for society's problems, pride at producing something useful as well as the drive to earn money and face new challenges:
[...] the idea to create a company was: I'm doing all these interesting things that could save the world [...] what's it going to bring? A handful of articles? That's not going to satisfy me [...] Every chemist has that ideal of: you see that factory there? They're using a process that I developed. [...] That desire to leave your mark on the world. Of course, l'd like to make money from it as well [...]

Table 5 summarizes the major motivations and motivational goals identified in the study for researcher involvement in UITT, organized in accordance with the classification proposed by Tamayo and Paschoal (2003).

\section{Deterrents for researcher involvement in UITT}

Among the factors that negatively affected the motivation of researchers in UITT, was their excessive number of activities at Brazilian universities. In addition to their teaching responsibilities, researchers also had to balance the time required for UITT with that needed to conduct studies, serve as student advisors and publish articles. UITT demands additional time from researchers in order to interact with companies and academic TT support structures, particularly in Brazil where the procedure is still new, bureaucratic and lengthy. The remarks of an inventor from the Chemistry Department at UFMG illustrate this point:

\begin{tabular}{|l|l|}
\hline Motivation & Motivational Goals \\
\hline Self-direction & $\begin{array}{l}\text { Generate resources: generate funds for research, reagents, equipment, to maintain students. } \\
\text { Create independents from government sources - sustainability for the continuity of research }\end{array}$ \\
\hline Stimulation & $\begin{array}{l}\text { Solve problems: generate useful knowledge, cater to the demands of companies } \\
\text { Professional challenge: commitments to companies (the need to meet targets and deadlines - } \\
\text { produce results), acting on new professional fronts, personal challenge }\end{array}$ \\
\hline Hedonism & $\begin{array}{l}\text { Personal gains: financial gains for the researcher, gratifications } \\
\text { Personal gratification: the pleasure of generating solutions, personal achievement, pride at }\end{array}$ \\
\hline Universalisment & $\begin{array}{l}\text { Academic prestige: recognition from peers (for expertise in the field, patents, participation in } \\
\text { Competition: between researchers to generate patents, licensing, create spin-offs }\end{array}$ \\
\hline $\begin{array}{l}\text { Solving the problems of society: meeting social demands, producing free knowledge, social in- } \\
\text { Motivating students: noticeable interest by students in applied research and TT, in creating/par- } \\
\text { ticipating in companies, awakening new prospects for the future } \\
\text { Generate new career paths for students: positions in partner companies, entrepreneurship/cre- } \\
\text { ating companies, improving training }\end{array}$ \\
\hline
\end{tabular}

Table 5. Motivations and motivational goals of academic scientists for UITT

ISSN: 07 I8-2724. (http://www.jotmi.org)

Journal of Technology Management \& Innovation @ Universidad Alberto Hurtado, Facultad de Economía y Negocios. 
being a good researcher is already a Herculean task. Advising students, publishing internationally, gaining recognition, earning $\mathrm{CNPq}$ grants and additional projects. All of this already demands a lot of work. [...] what discourages researchers is this: how can I balance this world with my work as a professor? It's difficult.

Also related to the time required to engage in UITT is the fear of being unable to maintain the high level of publications demanded by academia and having to withhold them since, in the case of patenting, applications must be lodged before publishing the research results.

TT managers from both UFMG and USP share the view that the difficulty professors face in obtaining permission to contribute to projects in partnership with companies compromises UITT, discouraging them. The feeling is that universities should recognize its importance and allow greater flexibility to enable professors to devote more time to UITT processes in certain instances.

As well as the difficulties involved, there are no incentives to compensate for the additional effort required to participate in UITT.The remarks of a researcher in the Department of Pharmacy at USP summarize a common feeling among academics, which adversely affects their motivation:"it's nothing but trouble, because it just means more work and my salary doesn't increase".

There are also too many regulations that restrict entrepreneurial possibilities for researchers, especially in public universities. As a result, many are apprehensive about breaking both formal (norms and regulations) and informal (embedded in academic culture) academic rules, which still largely reject applied research and projects in conjunction with industry, the patenting and licensing of technologies and participation by researchers in companies. A researcher from the Chemistry Department sums up these deterrents: "it's the time, the effort, the fear you may be doing something that contravenes university regulations. The fear of judgment from your peers, colleagues, etc.".

In addition to internal university issues, researchers and academic managers highlighted a series of motivational barriers in the UITT development process involving the Brazilian innovation environment. One such obstacle is inadequate legislation to encourage the creation of technology-based companies and deal with UITT processes in general.According to a researcher from USP and partner in an academic spin-off, in Brazil it's almost impossible to consider creating a truly technological company using national technology and applying all the rules of legislation. [...] Here, if it's not explicitly stated that it's permitted, it's prohibited. This hampers any type of technological development.

Bureaucracy is another deterrent for researchers in UITT, encompassing everything from establishing formal agreements to conducting joint studies, obtaining funding or even forming companies, as well as other UITT processes. In the words of a researcher in Mechanical Engineering at PUCRio, founder of an academic spin-off,

[...] the process (of technological development) has become very bureaucratic. [...] a framework of rigid regulations [...] it's impossible to plan exactly how the money will be spent. [...] it's extremely difficult and causes delays. [...] the bureaucracy that we inevitably encounter even when we have funding, the difficulty in spending the money, also interferes.

Difficulties are also encountered in the Brazilian corporate culture, wary of taking risks and the long-term investments needed to develop technologies, which negatively influences the motivation of researchers. According to a scientist from the Information Technology department of PUC-Rio, "what usually happens is that local businessmen find it's easier to buy from abroad than develop". Furthermore, the importance of academia is often not perceived by executives, and companies have repeatedly been reluctant to pay royalties on the commercialization of products developed through joint research with universities. The statement below summarizes the perceived cultural barriers to the process:

I think culture is the main obstacle in the transfer issue. Both the internal culture of universities and that of companies, their willingness to pay royalties to universities. Their understanding, for example, that universities play an important role in the development of technology. [Incubator manager at PUC-Rio]

In light of the barriers encountered within the Brazilian context, many academics expressed variations of the same opinion identified in a statement by a researcher and founder of a spin-off from USP: "if we focused on all the problems we face, we'd stay put and give up because it's much easier... the system is extremely demotivating".

Table 6 summarizes the factors that discourage the involvement of researchers in the UITT process in Brazil. 


\section{Discussion}

The determinants of motivation cannot be separated from the context and individual characteristics of researchers (Bergamini, 2008; Baldini, 20II). Thus, it is important to underscore the significance of Brazilian researcher's experiences at universities abroad, in countries where the innovation environment and UITT processes were more highly developed and consolidated. For many researchers these experiences were their first contact with UITT processes, enabling them to envision new professional prospects, modify certain values and break from previous prejudices. This awakened new aspirations as well as personal and professional goals, motivating their involvement in UITT in Brazil.

The most prominent personal characteristics identified among researchers engaged in UITT were determination, persistence and entrepreneurship. These traits are related to the motivational types self-direction (having autonomy) and stimulation (facing challenges), which express individual motivation to follow personal intellectual interests through ambiguous and uncertain paths, aspects associated to openness to change (Tamayo and Paschoal, 2003).

It is assumed that these motivations have been necessary in order for scientists to overcome obstacles to the UITT process in Brazil which, being recent, still faces a series of cultural, legal and procedural barriers (Zawislak and Dalmarco, 20I I; Closs et al., 20I2a). In opposition to the aforementioned motivations, the motivational types conformity, tradition and security, whose motivational goals involve the search for stability and preserving the status quo (Tamayo and Paschoal, 2003), were not identified in the present study. We found a predominance of motivations related to the individual. In addition to self-direction and stimulation, hedonism, achievement and power were also observed, whose motivational goals are similar to those found in previous studies.Among these were: generating resources (Link et al., 2007; Santana and Porto, 2009), personal gains (Baldini, 2010; Caldera and Debande, 2010), academic prestige (Baldini, $20 \mathrm{II})$, solving problems, personal gratification and solving the problems of society (Closs et al., 2012b).
A prominent motivational type observed in this study was that of power, related to competition for achieving prestige and status among academic peers involved in the UITT process, an aspect previously identified in Brazil by Closs et al. (2012b). It was found that, until recently, the battle for prestige in the competitive arena of Brazilian academia was centered on publishing scientific articles. Once UITT caused a shift in the perceived value and professional identity of scientists (Jain et al. 2009), the generation of patents, licenses and the creation of academic spin-offs as well as other initiatives linked to UITT, also became the focus of competition, motivating other researchers to take similar paths.

This has led to a cultural change in Brazilian academia - albeit on a small scale - encouraging new scientists to take part in UITT, thereby providing special contributions to the process (Hoye and Pries, 2009; Thursby et al., 2009; Garnica and Torkomian, 2009; Closs et al., 2012a) and the country's development. Moreover, extensive dissemination of success cases, as suggested by Baldini (2006) and observed among the participants, encourages other researchers to get involved, contributing towards broader changes in academic culture, promoting the recognition and enhancement of UITT activities.

None of those surveyed reported financial gains as the primary motivation for involvement in UITT. However, although few interviewees clearly acknowledged this motivator, most considered it a legitimate right to earn money from inventions generated through their research results. This perspective suggests that Brazil is also experiencing a break from the professional identity of the academic scientist, traditionally opposed to the appropriation of knowledge and profitability (Jain et al., 2009).

A noteworthy element of the present study, not observed in previous investigations, was the identification of the motivational type universalism, whose motivational goals involve awakening and maintaining the interest of students through UITT, as well as opening new career opportunities for them. In Brazil, investment in cutting edge technology by industry is still low (Corrêa, 2007), with little acknowledgement

\begin{tabular}{|l|l|}
\hline Factors & Description \\
\hline $\begin{array}{l}\text { Time required of } \\
\text { the researcher }\end{array}$ & Difficulty balancing time between teaching, research, publications and TT activities. \\
\hline Lack of incentive & More work for the same salary; little money. \\
\hline Fear & Fear of contravening university rules, withholding publications, the judgment of colleagues. \\
\hline $\begin{array}{l}\text { Innovation envi- } \\
\text { ronment }\end{array}$ & $\begin{array}{l}\text { Drawn out patenting and licensing process, bureaucracy, inadequate legislation, lack of } \\
\text { investment, disinterest on the part of companies }\end{array}$ \\
\hline
\end{tabular}

Table 6. Factors that discourage the involvement of researchers in UITT

ISSN: 07 I8-2724. (http://www.jotmi.org)

Journal of Technology Management \& Innovation @ Universidad Alberto Hurtado, Facultad de Economía y Negocios. 
of universities as technological sources (Santana and Porto, 2009). Within the corporate setting, where the market for absorbing highly qualified students remains limited with little appreciation of this professional profile, the contribution of professors/researchers to UITT is motivated by the possibility of creating new professional arenas.

In regard to deterrents to the participation of academic inventors, the difficulties encountered by professors/researchers in balancing their time between teaching, research and advising students and the dedication required for the UITT process is corroborated by earlier Brazilian studies (Santana and Porto, 2009; Closs et al., 20I2b). Likewise, the lack of incentives or adequate rewards is also identified in other investigations (Baldini, 20I0; Caldera and Debande, 20I0).

A feeling that often has a negative influence on motivation and prevents action is that of fear. At times, participation in UITT provoked negative reactions from the colleagues and superiors of those involved in the process. The fear of experiencing such situations and breaking from prejudices deters researchers unwilling to leave their comfort zone to take on such challenges. The excessive number of rules, restrictions and inaccuracies in regulations that govern the roles of professors and universities, particularly at public institutions, provokes a fear of infringement among professors regarding UITT, since there are no clear boundaries between what is permitted and what is not. In this respect, managers and researchers emphasized the need to create clear university regulations for participation in UITT, which not only gives researchers greater security, but also signals approval by the institution, thereby establishing the process as legitimate (Baldini, 2006).

Among the deterrents to TT highlighted in the Brazilian context were: lengthy patenting and licensing processes for inventions; the bureaucracy involved in the process; lack of adequate legislation; the academic culture; lack of investment and disinterest on the part of companies. Although those surveyed reiterated these barriers, recurrent in national studies (Correa, 2007; Zawislak and Dalmarco, 20I I; Closs et al., 20I 2a), they also acknowledged a series of positive changes occurring in Brazil. The process of change is slow, but interviewees have noticed an increase in interest from companies, and greater government investment and effort to professionalize academic UITT support structures. There is a notable convergence of effort to promote UITT, particularly by the government and universities, creating a favorable environment for the development of this process in the country.

\section{Final Considerations}

Based on the scarcity of research investigating the motivators and deterrents for academic scientists in the UITT process in Brazil, this study analyzed and systematized these aspects identified among researchers and academic managers in the country, contributing to broadening the literature on the theme.

Knowledge of the motivational profile of the academic scientists surveyed favors the development of suitable incentive policies and programs for UITT, since motivational strategies are more effective when they correspond directly to professional goals (Tamayo and Paschoal, 2003). Thus, the aim is to provoke debate and provide subsidies to develop initiatives that contribute to maintaining the motivation of academic scientists already involved in this process, and encourage new inventors to participate in UITT.

Academic policies and programs centered on this goal would also attract and retain qualified researchers interested in UITT at national universities, discouraging them from pursuing professional opportunities in countries where the process is more advanced. This debate is increasingly important in Brazil at a time when the government is seeking to foster technological innovation by strengthening the supply chain, in order to expand the country's participation in more competitive global markets, adding value to its products (Brazil, 20I I).

Further quantitative research is needed to validate the findings of the present study, as well as additional research aimed at understanding other aspects of the professional profile of academic scientists involved in UITT, such as investigating what skills are required and how these professionals manage their work in order to participate in these different professional fronts. 


\section{References}

BALDINI, N. (2006). University patenting and licensing activity: a review of the literature. Research Evaluation, I5(3), 197 207. doi: http://dx.doi.org//0.3/52//47/5440678I775878

BALDINI, N. (2010). Do royalties really foster university patenting activity? An answer from Italy. Technovation, 30, 109-116. doi: http://dx.doi.org/10.1016/j.technovation.2009.09.007

BALDINI, N. (20I I). University patenting: patterns of faculty motivations. Technology Analysis \& Strategic Management, 23 (2), I03-I2I. doi: http://dx.doi.org// 0.1080/09537325.20 II.543329

BALDINI, N., Grimaldi, R., Sobrero, M. (2007). To patent or no to patent? A survey of Italian inventors on motivations, incentives and obstacles to university patenting. Scientometrics, 70(2), 333-354. doi: http://dx.doi.org// 0.5465/ ambpp.2005.18783536

BERGAMINI, C. (2008). Motivação nas organizações. São Paulo:Atlas.

CALDERA, A., Debande, O. (2010). Performance of Spanish universities in technology transfer: an empirical analysis. Research Policy, 39, I I60-I I73. doi: http://dx.doi.org//0.1016/j. respol.2010.05.016

CLOSS, L., Ferreira, G. C., Sampaio, C. H., Perin, M. G. (2012a). Organizational Factors that Affect the University-Industry Technology Transfer Processes of a Private University. Journal of Technology Management \& Innovation, 7(I), I04-I 17. doi: http://dx.doi.org/I0.4067/S07/8-272420I2000I00007

CLOSS, L., Ferreira, G. C., Sampaio, C. H., Perin, M. G. (20I2b). Intervenientes na Transferência de Tecnologia UniversidadeEmpresa: o Caso PUCRS. Revista de Administração Contemporânea, 16, 59-78. doi: http://dx.doi.org//0.1590/s |4|565552012000100005

CLOSS, L., Ferreira, G. C. A Transferência de Tecnologia Universidade-Empresa no Contexto Brasileiro: uma Revisão de Estudos Científicos Publicados entre os anos 2005 e 2009. Gestão \& Produção, 19, 419-432. doi: http://dx.doi. org/I0.1590/s0I04-530×20I20002000I4.

CORRÊA, F. (2007). A patente na universidade: contexto e perspectivas de uma política de geração de patentes na Universidade Federal Fluminense. Master's Dissertation. Universidade Federal Fluminense, Niterói.
DALMARCO, G., Dewes, M., Zawislak, P., Padula, A. (20II). Universities' intellectual property: path for innovation or patent competition? Journal of Technology Management \& Innovation, 6(3), I59-169. doi: http://dx.doi.org//0.4067/ s07I8-272420II0003000I2.

D'ESTE, P., Mahdi, S.; Neely, A.; Rentocchini, F. (20I2). Inventors and entrepreneurs in academia: what types of skills and experience matter? Technovation, 32, 293-303. doi: http:// dx.doi.org/10.1016/j.technovation.20II.12.005.

ETZKOWITZ, H. The evolution of the entrepreneurial university. International Journal Technology and Globalization, v. I p. 64-77, 2004. doi: http://dx.doi.org//0.1 I I I/j.I4676486.2010.00995.x.

FUJINO,A., Stal, E. (2007). Gestão da propriedade intelectual na universidade pública brasileira: diretrizes para licenciamento e comercialização. Revista de Negócios, I2(I), 104120.

GIMENEZ, A., Bonacelli, M., Carneiro, A. (20I2). The Challenges of Teaching and Training in Intellectual Property. Journal of Technology Management \& Innovation, 7(4). doi: http:// dx.doi.org/I0.4067/S07| 8-272420I20004000 I4

GARNICA; L., Torkomian, A.L. (2009). Gestão de Tecnologia em universidades: uma análise do patenteamento e dos fatores de dificuldades e de apoio à transferência de tecnologia no Estado de São Paulo. Gestão \& Produção, 16 (4), 624-638. doi: http://dx.doi.org/I0.1590/s0 I04-530×20090004000 I I

HOYE, K., Pries, F. (2009). 'Repeat commercializers', the 'habitual entrepeneurs' of university-industry technology transfer. Technovation, 29, 682-689. doi: http://dx.doi. org/I0.1016/j.technovation.2009.05.008

JAIN, S., George, G., Maltarich, M. (2009). Academics or entrepreneurs? Investigating role identity modification of university scientists involved in commercialization activity. Research Policy, 38, 922-935. doi: http://dx.doi.org//0.1016/j. respol.2009.02.007

LINK,A., Siegel, D., Bozeman, B. (2007). An empirical analysis of the propensity of academics to engage in informal university technology transfer. Industrial and Corporate Change, I6 (4), 64I-655. doi: http://dx.doi.org//0.2/39/ssrn.902207

MERRIAM, S. (2002). Qualitative research in practice: examples for discussion and analysis. San Francisco: Jossey-Bass.

PÓVOA, L. (2008). Patentes de universidades e institutos públicos de pesquisa e a transferência de tecnologia para empresas no Brasil. Doctoral Thesis. Universidade Federal de Minas Gerais, Belo Horizonte. 
PÓVOA, L., Rapini, M. (2010). Technology transfer from universities and public research institutes to firms in Brazil: what is transferred and how the transfer is carried out. Science and Public Policy, 37 (5), 369-379. doi: http://dx.doi. org//0.3152/0302342/0x4966/9

SANTANA, E., Porto, G. (2009). E agora, o que fazer com essa tecnologia? Um estudo multicaso sobre as possibilidades de transferência de tecnologia na USP-RP. Revista de Administração Contemporânea, I3(3), 410-429. doi: http:// dx.doi.org/|0.1590/s |4| 5-65552009000300005

SIEGEL, D., Waldman, D., Atwater, L., Link, A. (2004). Toward a model of effective transfer of scientific knowledge from academicians to practitioners: qualitative evidence from commercialization of university technologies. Journal of Engineering and Technology Management, 21, II5-142. doi: http://dx.doi.org/I0.1016/j.jengtecman.2003.12.006

TAMAYO, A., Paschoal, T. (2003). A relação da motivação para o trabalho com as metas do trabalhador. Revista de Administração Contemporânea, 7(4), 33-54. doi: http://dx.doi. org/|0.1590/s | | I5-65552003000400003

THURSBY, J., Fuller, A., Thursby, M. US faculty patenting: inside and outside the university. Research Policy, 38, 14-25, 2009. doi: http://dx.doi.org// 0.3386/w/3256

THURSBY, J., Thursby, M. (20II). Faculty participation in licensing: implications for research. Research Policy, 40(I), 2029. doi: http://dx.doi.org//0.1016/j.respol.2010.09.014

ZAWISLAK, P., Dalmarco, G. (20I I). The silent run: new issues and outcomes for university-industry relations in Brazil. Journal of Technology Management \& Innovation, 6(2), 66-8I. doi: http://dx.doi.org/I0.4067/s07 I8-272420I I 000200005 